\title{
The Circulating Library, the Novel, and Implicit Practices of Comparing in Eighteenth-Century England: Assembling 'Middle-Class' Literariness
}

Ralf Schneider

Mr. Bennet was glad to take his guest into the drawing-room again, and, when tea was over, glad to invite him to read aloud to the ladies. Mr. Collins readily assented, and a book was produced; but, on beholding it (for everything announced it to be from a circulating library), he started back, and begging pardon, protested that he never read novels. Kitty stared at him, and Lydia exclaimed. Other books were produced, and after some deliberation he chose Fordyce's Sermons. Lydia gaped as he opened the volume, and before he had, with very monotonous solemnity, read three pages, she interrupted him [...].

Jane Austen, Pride and Prejudice [1813] 2001: 47

\section{The Circulating Library, Literary Sociology and the Sociology of Associations}

The scene from Austen's classic novel, Pride and Prejudice, can be read as an invitation to disentangle the reasons for both Mr Collins' horror at the sight of a book from the circulating library which he immediately identifies as a novel, and the Bennet girls' dismay at his choice of an alternative. I will return to the joke, which Austen makes at the expense of the young clergyman in this scene, later. For the present, I take the passage from an early nineteenth-century novel as a starting point for a retrospective enquiry into the origins of the complex connections it contains. The short scene involves issues of class, gender, age, material culture, ideology, sociability, book format and literary genre, and I will argue in this essay that in the course of the 'long' 
eighteenth century, the circulating library, as an institution and as a public space, was closely associated both with the performance of a new class identity and the development of the new literary genre of the novel; ${ }^{1}$ furthermore, the material and ideological conditions of book-lending, the bodily presence of the novel-reading public, and the physical materiality of the books were centrally involved in this association. I propose to look at these phenomena from a perspective that combines impulses from historical literary sociology and from Actor Network Theory, because I consider such an alignment best suited to assess their complexity.

Much evidence survives on the eighteenth-century circulating library: historians of the book and the literary system have assessed and interpreted the libraries' catalogues, business papers, subscription books, advertisements and trade cards, reports about circulating libraries in diaries and letters as well as mentioning of and invectives against them in pamphlets, sermons, letters to journal editors, caricatures, novels and plays. ${ }^{2}$ Instead of buying novels, most readers would subscribe to a circulating library that allowed them to take out a volume or two at a time, for a fee levied annually or per quarter that amounted to just twice the sum one would have to expend on a single printed and bound novel. The phenomenon had its roots in Restoration England, when Francis Kirkman opened the first commercial circulating library in 1661 (Feather 1988: 57), but it first became a wide-spread institution after Alan Ramsay had opened his library in Edinburgh in 1725 and Samuel

The label 'novel' can be applied to prose narratives from the largest part of the 18th only retrospectively, since the word only slowly gained prominence among other genre classifications such as 'romance', 'history', 'live', 'adventure', 'account', 'tale', 'memoir', etc. (Hunter 1996: 9). On the mixture of genres from which what we now recognize as novels emerged, see the classical study by Hunter (1990) and the more recent one by Stein (2020).

2 Among the early contributions are McKillop (1934) and the meticulous study by Hamlyn (1946), as well as Kaufman (1967); see also Stewart-Murphy (1992) and the helpful articles by Jacobs $(1995,2003,2006)$. Much information on the statistics, economics, and practices pertaining to the circulating library can also be found in Erickson (1990), Skelton-Foord (1998 and 1999) and Manley (2000). See also the extensive assessment of the production and distribution system for fiction between 1770 and 1779 by Raven (2000), which is also informative on circulating libraries, their owners and business practices, and on the economic and material conditions under which novels found their readers. See also Raven's other indispensable contributions to the history of the circulating library $(1990,1996)$, the private subscription library (2006) and the economy of book production, distribution and reception in the period under scrutiny (2009). 
Fancourt his London establishment in 1740 . When the idea of the circulating library caught on, many more were opened in London and then in almost every other major English city and town, particularly from the 1750 s on. It is uncertain whether the number of such libraries across Great Britain actually reached the astonishing "not less than one thousand" in the provinces at the end of the century that the Monthly Magazine mentioned in April 1801, or how many "more than 100 in London" there actually existed in the end (qtd. in Kaufman 1967: 10; Brewer 1997: 178). But there is no doubt that the institution was both widespread and its establishments numerous. ${ }^{3}$ There were also other types of libraries, such as the subscription library and the book club, "the former specialising in serious non-fiction, and only few novels, the latter usually featuring the small pamphlets and printed ephemera in which contemporary religious controversies were vehemently rehearsed" (Brewer 1997: 180). ${ }^{4}$ When the term 'library' is used hereafter, it refers exclusively to the commercial circulating library. Towards the end of the century, readers could get access to fiction in three ways, "the purchase of new novels, the purchase of novels second-hand, and the renting of fiction" (Skelton-Foord 1998: 349). However, all scholarly contributions on the topic agree that the standard mode of accessing newly printed titles, especially novels, throughout the period was by frequenting circulating libraries. Furthermore, there is much agreement that the libraries developed into social meeting places for the well to-do and fashionable society, not only in London but also in the provincial libraries and particularly in holiday resorts (Manley 2000: 32). The economic, spatial, and

3 Jacobs, using figures quoted by Hamlyn (1946) and Kaufman (1967) summarizes that already "by the 1750 s there were at least nine circulating libraries in London", adding that "here as elsewhere records surely underestimate numbers. By 1780 there were at least nineteen and by 1800 at least twenty-six libraries in London [...]." (2006: 5) Manley (2000: 35) counts "three circulating libraries in Bath" alone in 1750, and adds that "by 1800 there were ten, plus a music library".

4 See also Manley (2000: 29): "Book clubs were usually temporary collections, where the books were sold off each year. Proprietary subscription libraries and book clubs were almost always organizations in which the members held shares in a common stock and collected usually, but not exclusively, the better class of non-fiction for the benefit of all." The type of sociability associated with the subscription library was different from that of the circulating library, because membership in the former was more expensive and mostly restricted to men; see Raven (2006). For general information on the relationship between the book market and libraries, see Feather (2006). 
social aspects of these libraries were, as I will demonstrate below, instrumental in the production of the middle-class literary sphere.

Although approaches such as Book History (or History of the Book), Bibliography, Sociology of Texts, Sociology of Authorship and Reading constitute a broad and varied field, they share the conviction that the literary sphere is fundamentally shaped by the intermingling of the personal, material and economic factors of book production, distribution and reception. ${ }^{5}$ Historical Literary Sociology, to use an umbrella term for the approaches just mentioned, has reminded scholars in literary hermeneutics time and again of the intricate connectedness between what is in a book and how that book comes into being, how it reaches readers, and how it exists as a material artefact that implies ideas and evaluations beyond the content-level of the book. ${ }^{6}$ Within the social sciences, the study of phenomena of the past and the present has increasingly taken material artefacts seriously, not merely as products or tools, but as unities that are fundamentally and actively involved in social phenomena, just as people, discourses, and practices are. For the purposes of the present essay, Actor Network Theory (ANT) is particularly attractive because of its predilection for complex phenomena in the process of their emergence, for fuzzy fields of social activity in which agents, or actors, of different kinds - human beings and their bodies, material artefacts, practices, and ideas create associations. In them, none of the actions or actors precede, predetermine, or fully explain any of the others, but they may emerge locally, spontaneously, and temporarily (Latour 1996, 2005). Felski summarizes the central idea of ANT as follows: "The social [...] is not a preformed being but a doing, not a hidden entity underlying the realm of appearance but the ongoing connections, disconnections, and reconnections between multiple actors" (2015: 158). An actor, she clarifies later, "is anything that modifies a state of affairs by making a difference" (163), which refers also to non-human entities, without, however, implying that non-human actors have intentionality or follow a purpose. What is observable as the social sphere is the outcome of connections, disconnections and reconnections, not their basis. In the words of Latour,

5 For seminal contributions to this field, see McKenzie (1986), Adams/Barker (1993), and the texts reprinted in Finkelstein/McCleery (2006). Raven (2018) gives an overview of the scope of the field.

6 To be fair, Genette's (1997) concept of the paratext must be mentioned here, since it also refers to the relationship between authors, books as material artefacts, and readers, taking also the physical appearance of the book into account. 
"it's not the social that accounts for associations but rather associations that explain the social" (2005: 238).

Literary scholars may admittedly treat ANT with some suspicion. The tension between Bruno Latour's famous questioning of all component terms of the approach ("there are four things that do not work with actor-network theory: the word actor, the word network, the word theory and the hyphen!" 1999: 15) and his wholehearted defence of the project in Reassembling the Social (2005) may justify some reluctance to getting involved with it, as does the persistent metaphoricity and counter-intuitiveness of his language, which seems to defy clear-cut definitions and easy accessibility. However, not only are there influential supporters from within literary studies, including Rita Felski in her Limits of Critique (2015: 151-185). It is also especially intriguing to look at the development, features and effects of the practice of book-lending and the institution of the circulating library through an ANT lens, because neither of them, nor what one would classically call their 'social context', were simply there. As Bermingham (1995: 15) phrases it, "a culture-consuming public of the early modern period was there not so much to be tapped as to be created". Historians of culture such as Brewer (1997) and others (Bermingham/Brewer 1995, Hume 2006) have shown in both depth and detail that none of the many areas of cultural production (print culture, performance culture, the visual arts, music, etc.) were readily available for the broadening audiences when the (long) eighteenth century started. Rather, they co-emerged - slowly, not teleologically, in phases that saw both advances and setbacks - with and through the complex associations of concepts, bodies and artefacts, including spaces. This is of particular relevance for the emergence of the novel, which, according to Feather "is the only literary genre to have been invented since the invention of printing", so that "its literary history is inseparable from the history of its publication" (1988: 57). I take "publication" to include the mode of distribution on which I will focus below. To adopt an ANT perspective is to give precedence to the emergent and contingent, the tentative and unstable, to ties and associations that must be retrieved from the surviving data. The growth of the circulating library during the long eighteenth century and the development of the novel as a major genre, which were in turn coextensive with the social and cultural shifts towards a modern consumer society, are phenomena that lend themselves particularly well to an interpretation inspired by ANT. I will argue that access to the novel through the circulating library involved practices of performance of class identity for the emerging middle stratum of society, and that these performances possessed a crucial comparative aspect. 
If there are three narratives of development - that of the novel, that of the circulating library, and that of the middle classes - none of them precedes, pre-determines, or encompasses the others. Rather, these developments can be seen as associations, or networks, which were mutually indebted to each other.

\section{Social Change and Literature: Book-Lending, the Performance of Politeness, and Implicit Practices of Comparing}

The eighteenth century is generally regarded as a period of drastic changes, and it is also one of considerable ambivalences. The period saw the transition of British society from a pre-modern society structured by hierarchical classification to a modern one, organized through functional differentiation. ${ }^{7}$ It also saw the development of a modern literary system. The standard historical account of the interrelated changes put forward by historians of literature, publishing, and the book as a material artefact on the one hand, and of class, society and economy on the other, is the following: The lapse of the Licensing Act in 1695 effectively ended pre-publication censorship and stripped the London Stationers Company of its monopoly, so that both metropolitan and provincial printing businesses could flourish by and by; ${ }^{8}$ the population grew, and education in literacy for boys and, later, also girls increased, which created a growing readership and demand for reading material, so that "[s]ome literary and cultural historians have identified alongside, and related to, the

This is the sociological position that, for instance, Talcott Parsons and Niklas Luhmann share. See, e.g., Parsons (1969) and Luhmann (1977).

8 See Feather (1988: 67-125) for an account of the development of the market for printed material; Belanger (1982) and Benedict (2004) provide concise overviews. While the number of master printers in London had been restricted to twenty under the Licensing Act, when Samuel Richardson set up shop in the 1720 s "there were already more than seventy-five master printers in London; at his death in 1761 more than 120 were at work, and their premises grew as their work and numbers expanded" (Brewer 1997: 137). This multiplication of producers of printed material also occurred in the provinces, so that for instance in the larger town of Newcastle upon Tyne, in 1790 as many as twenty printers were at work (ibid.). Although not all printing houses produced novels, these figures give a good impression of the scope of the more general development of the printing press, from which the novel also profited. 
social changes of the eighteenth century a 'reading revolution"' (Williams 2017: 6). 9

Grounded in a mentality of improvement that dates back to the seventeenth century (Slack 2015), a set of further 'revolutions' marked Britain's shift from a pre-modern to a modern society: the financial, the agrarian, the consumer, and eventually the beginnings of the industrial revolution. All in all, since the number of ways in which people could acquire wealth and status multiplied, these developments can be understood to be the foundation upon which a social stratum below the upper gentry and above the labourers developed. ${ }^{10}$ It is debatable whether the term 'revolution' is the best designation for all of these developments, each of which had its own phases of advancement and regression, success and failure. There is no doubt however, that we are looking at a multifactor dynamic of substantial changes between the late seventeenth and the early nineteenth centuries.

There has been a tendency in literary and cultural history to link the dissemination of print with the rise of a bourgeois mentality since Jürgen Habermas' study of the public sphere (1989). The novel in particular has been understood to be involved in this process, as Watt (1957) stated in his classical study, which was critically revaluated by McKeon ([1987] 2002), a classic by now, too. The 'middling sorts' can be regarded as an emerging social group whose moral ideals, opinions, and habits needed constant formulation and

For England alone, Hunt (1996: 17) quotes a growth in population between 1700 and 1800 "from approximately five million to eight and one-half million". Raven summarizes that the British population more than doubled in the period under consideration: "The British Isles in 1695 comprised three kingdoms with a total population of just over 8 million. In 1814 a United Kingdom of Britain and Ireland contained a population of some 19 million" (2006: 243). According to Hunter (1996: 21), by the mid-eighteenth century "at least 60 percent of the adult men in England (and perhaps more) could read and write", while "literacy increased among women faster than among men", starting from a lower percentage and reaching at least 40 percent by mid-century. The articles in Rivers (1982) demonstrate the breadth and variety of sections of publishing and readership, from religious, political, scientific and philosophical to belletristic reading. See Colclough (2007: 1-117) for a general history of reading practices in eighteenth-century England, based on the analysis of individual cases.

For general historical surveys of the socio-economic changes, see Earle (1989) on the early decades, and Davidoff/Hall (1987) on the period since 1750; further standard sources include Porter (1991), Barry/Brooks (1994), Smail (1994), Hunt (1996), and Langford (1989 and 2010); see also Barry's extensive review (1991). 
affirmation, and the novel can be understood as a platform for the negotiation of that mentality (Langford 2010: 390-398). However, as a period of transition, the long eighteenth century presents a much more ambivalent and heterogeneous picture both socioeconomically and culturally. The time was still characterized by serious political and religious rifts, and though the middling sorts may have been rising, the political and economic primacy of the aristocracy and the landed gentry was not simply replaced (see, e.g., Spurr 1998). As with the 'rise' of the middle classes, we need to bear in mind that the novel also 'rose' slowly, and most perceptibly in the second half of the eighteenth century. Daniel Defoe stands out as a fairly solitary figure for the first half of the century, while the bulk of male and female authors who are now regarded as 'fathers' and 'mothers' of the English novel are located in the second half, with Samuel Richardson (Pamela 1740, Clarissa 1748) and Henry Fielding (Shamela 1741, Joseph Andrews 1742) as the early figures of that group, followed by Laurence Sterne (Tristram Shandy from 1759 on), Oliver Goldsmith (Vicar of Wakefield 1766), Tobias Smollett (Humphry Clinker 1771), and Frances Burney (Evelina 1778), as well as the Gothic novels reviving after Horace Walpole's Castle of Otranto (1764) towards the end of the century (Ann Radcliffe: Mysteries of Udolpho 1794, Matthew Lewis: The Monk 1796).

In the transition from the post-Restoration period to the eighteenth century, more ranks slowly joined the upper gentry as audiences for cultural products, which created new markets: "The economic history of the eighty years at issue here [i.e., 1660-1740; RS] is essentially the story of how the buying power of citizens and the lesser gentry increased to the point at which serious money could be made by appealing to the taste of what we would now call middle class consumers" (Hume 2006: 498). Novel production boomed in the later part of the century, and the canonical classics of eighteenth-century literature just mentioned were drastically outnumbered by the flood of new fashionable novels, most of which were romantic or gothic fictions. ${ }^{11}$ That the boom of the circulating library occurred from the 1750 s on can be aligned with this time frame. However, it is the point of an ANT-informed approach that we should not first reconstruct the 'social structure' of the period from documents and history books, to see how the practice of book-lending then 'fits' in

11 For the sheer scope of the output of various types of prose fiction that can be classified as 'novels', see the astonishing number of 1.421 titles of first publications listed by Garside, Raven and Schöwerling (2000) for the last three decades of the eighteenth century, which amounts to one new novel almost every week. 
this framework. Rather, we need to understand what people did, thought and felt when they frequented the circulating library, how they interacted there, how they handled the artefacts, and how they evaluated their own and other people's behaviour.

British society at the time pondered a lot about, and spilled much ink on, precisely the question who constituted the 'middle classes', and modern scholarship has also been split over the issue as a consequence. The term 'class' itself became a common reference to contemporary society at the time, and it was variously defined and re-defined, as is to be expected from a period of transition and change. ${ }^{12}$ Hume (2006: 496) speaks of the "scholarly wars of the last forty years concerning the existence or non-existence of a 'middle class" in Early Modern England. While he is convinced that "[n]o such thing was recognized during the period 1660-1740 in any modern sense of that phrase" (ibid.), many other studies use the terms 'middle class' or 'middling sorts' in their titles (see, e.g., Davidoff/Hall 1987, Earle 1989, Barry/Brooks 1994, Smail 1994, Wahrman 1995, Hunt 1996). The absence of an explicit concept and widely used label for the middle classes until the mid-eighteenth century that Hume notes does not mean that ranks and their relations were stable. The processes of social change produced a shift in the evaluation of behaviour, with a concomitant change in the meaning of such terms as 'gentle' and 'gentleman'. The semantics of these words turned from being associated with noble birth, leisure and conspicuous consumption, to being applied to a mode of conduct and a disposition towards polite sociability (Corfield 1991: 106-107; Klein 1995: 364 and 2002: 872; Carter 2001: chapters 1 \& 2). I will argue below that the circulating library helped in the creation of polite sociability which covered ranks from the lower middle to the upper classes. Adding yet another item to the list of revolutions mentioned above, Raven claims that "there was a library revolution in eighteenth-century England" (1996: 175). Those members of British society that can in retrospect be termed 'the middle classes' were the ones who frequented the circulating libraries, because (1) they wanted to read novels, (2) they could afford to do so, and (3) they had something else to gain from it: an opportunity to publicly perform a middle-class lifestyle. To

See Corfield (1991 and 1996) and Wahrman (1995) on the shifts in social hierarchies and their designation throughout the eighteenth century. Downie (2003) points out that Habermas unduly locates the structural changes of British society at the beginning of the period, while they really took the entire eighteenth century, and in particular the second half, to develop. 
be sure, the bulk of the stock of circulating libraries would actually be nonfiction: figures quoted by Erickson (1990: 580 and 589, n. 34) suggest that the larger libraries held up to $80 \%$ of non-fiction titles. However, the smaller the businesses were, the more the balance was in the opposite direction, and the majority of titles that subscribers actually checked out were fiction; what is more, the figure of only $20 \%$ fiction titles "probably understates somewhat the libraries' emphasis upon novels, since large enterprises would stock multiple copies of recent fiction" (ibid: 580). Since new titles would be returned and could be handed out again within a few days, the actual reach of a new novel must be regarded as considerable.

Throughout the long eighteenth century, the price of a new printed and bound book deterred even affluent readers from wanting or being able to possess many. While classical literature, educational or religious works were usually deemed worthy of being purchased, books that were regarded as more ephemeral, such as novels, did not generally justify the expense. This was certainly true for workers: "Robinson Crusoe in 1719 cost five shillings (the bookstall price for its 364 pages in unbound sheets), and that was the equivalent of almost a week's wages for a young labourer" (Hunter 1996: 25). How did this apply to those who earned more than a young labourer? Assessments of the social composition of the circulating library clientele are somewhat contradictory. On the one hand, there are hints towards a democratisation of reading supported by the library: "Servants and other people of lower classes were beginning to read books, which they never would have bought but now could rent for a few pennies per week" (Kaufman 1967: 23). Book lending thus looks like the solution to the problem of exorbitant book prices. Charlotte Stewart-Murphy also lumps together various social strata who, according to her, congregated in "a new popular culture", to which the circulating libraries contributed:

For the first time, the subscribers to the libraries - the well-to-do, the middle-class professionals, working-men, merchants, shopkeepers, domestic servants, and their families - shared a common literary interest and began to develop a similar set of social values. (1992: 49)

On the other hand, however, scholars have calculated that "[m]embership fees and borrowing charges for commercial circulating and proprietary libraries were hardly affordable for most" (Raven 2000: 111), and that "[t] he patrons of the circulating libraries were not poor" (Brewer 1997: 177). Raven explains that "although such institutions [i.e., the commercial circulating libraries; R.S.] 
were notably cheaper than the expensive annual private subscription and proprietary libraries, cost remained prohibitive to all but the middle-class customers" (2006: 253), and Jacobs states: "Only middle and upper-class readers could reasonably afford circulating library fees before the twentieth century" (2006: 6) ${ }^{13}$ Manley situates the clientele even higher on the social scale: "Many of these libraries would have been beyond the means of a large number of people, and their advertisements are aimed at the higher classes" (2000: 40). It is safest, then, to think of the middle class as the most important patrons. A market for élite cultural products, such as paintings, the theatre, and the opera, continued from the Restoration period well into the eighteenth century, as Hume (2006) has shown: "Opera and painting were stratospherically expensive; theater was pricey; and books of the sort that contained plays and poems were by no means readily affordable by those of the "middling sort" (529). I would argue that this is precisely one reason for the success of the circulating library with its focus on the novel.

Beside the pecuniary aspect, it makes sense to associate the libraries with the middling sorts, broad as that spectrum was, because novel reading and the use of the circulating library depended on the availability, or lack, of leisure: "By allowing middle-class readers to consume hundreds of books for the price of buying two books, circulating libraries were key to the creation of a modern popular culture of reading, in which reading new books became a form of leisure activity" (Jacobs 2006: 6; my emphasis). True leisure, i.e., the absence of the necessity to pursue a profession for one's income, was still what differentiated the highest classes from the middle. However, to be seen lending or even possessing books could be a signal that just enough leisure was available to be associated with the 'better' sorts of people. To be seen in public with books thus came to metonymically signify class, and the women of the middle-class family, who had the most leisure-time to spend, were the ones who mostly performed that class association. Erickson sums up that "[i]n many respects, then, books and an apparent interest in them were signs of gentility and often

On prices see also Raven (2009: 96-102). On the general economic conditions of the production and consumption of high culture in the period between the Restoration and the mid-eighteenth century, see Hume (2006). This situation appears to have continued until the end of the period. Between the 1790s, "when prices began to rise astronomically" (Skelton-Foord 1998: 351), and the 1830s, when the first cheap reprint series were put on the market, "artisans and farm-labourers, for instance, would very rarely, if ever, have been able to afford to purchase new books" (ibid.). 
displayed only for their social utility" (1990: 576). This is true for the expensive leather-bound volumes that one might keep in the house, and it is also true for the interaction with books from libraries.

My emphasis on the double function of the circulating library as a bookdistribution institution and a place of class performance rests on a speculation that combines the concept of politeness with that of comparative behaviour. The ideal of politeness functioned as a guiding principle for a society that was perhaps not willing to dissolve hierarchies of class and status, but sought ways to bridge the differences (Langford 1989, Carter 2001, Klein 2002). Spurr (1998) contends that though the eighteenth century was one of major social, religious and political divides, the English managed to contain the differences by developing standards of social interaction, rational and civilized behaviour; and the shifting semantics of concepts such as 'gentle' or 'gentleman' mentioned above also point in the same direction. As Klein has shown, "what made eighteenth-century Britain a polite society was not its horizontal division between polite and non-polite persons, but rather the wide access of a range of persons to activities and competencies that contemporaries considered 'polite"' (2002: 869). Politeness was an ideal that related to decorum, restraint, pleasantness and sociability in life-style, habits and interpersonal communication, and it also affected matters of taste and fashion (ibid.: 874). The association of fashion and politeness is crucial here, because, as Klein stresses repeatedly, "a concern with the manner in which actions were performed, was perhaps the most important component of the meaning of politeness", and "[i]nfusing all was a strong dimension of display" (ibid.: 874 and 888; my emphasis). ${ }^{14}$ Performance and display only make sense in a public arena in which the standards of adequate behaviour either exist, or, as I claim for the emergence of a middle-class code of conduct, still need to be negotiated. I suggest that in a phase of emergent sociability, practices of comparing serve the function of negotiating the standards of adequacy or inadequacy of behaviour.

14 On the relevance of fashion in the eighteenth century, see Nunn (2000: 75-103) and Ribeiro (2002). The fact that upper-class dress became increasingly less ceremonious helped promote an "effacement of social distinction" and a "common genteel style of dressing" that the ranks below the aristocracy could adopt and afford (Klein 2002: 883). This tendency towards a democratisation of fashion has also been explored by Styles (2007). 
Comparing is a basic function of the human mind, and the wide-spread use of practices of comparing has been associated with modernity: whether in class systems, markets, or in processes of globalisation, comparing is part and parcel of the phenomena of competition, rivalry, power and dominance that are characteristic of Western, capitalist societies. ${ }^{15}$ As critics of colonialism have pointed out, the very notion of modernity involved a Eurocentric perspective and a comparative logic of progress and technological improvement that was used as a justification for the crimes of imperialism and aggressive foreign politics in general (e.g., Cheah 2003). In our context, three observations are important. First, while many scholars have looked at intercultural practices of comparing, social differentiation within a society also involves comparisons; I consider the eighteenth-century formation of a middleclass consciousness an effect of such intracultural comparing. Second, comparisons are never neutral nor 'innocent', because they tend to establish differences based on evaluations. Thus, when I contend that people from the middle classes in the eighteenth century compared their own behaviour to that of others, or that of other observed persons with regard to notions of politeness, I imply that they did so to distinguish themselves from those who fell outside the realm of the polite: both the lowest classes and the highest. To speak of comparisons between the middle and the upper classes, it is not necessary to assume that the middle classes strove to adopt or imitate the manners of the upper. Quite the contrary, practices of comparing may well establish a difference based on the assumption that this difference is beneficial. The aristocracy had, after all, a reputation of lacking virtue, a trait the middle classes certainly did not want to imitate. ${ }^{16}$ Third, comparing does not require explicit verbalization. Rather, I suggest that the simple act of appearing in public and displaying certain behaviours that can be associated with politeness has a comparative facet, in so far as places were public, i.e., if others who also performed and displayed their behaviour there, were also present. Politeness needed an audience: "The rise of politeness placed a new

See the contributions to Felski/Friedman (2013) for an assessment of the political history of comparisons; see Heintz (2016) for the sociological perspective. The comparative has also been a principle of literary and cultural studies since their inception, and its fruitfulness has recently been discussed and revaluated; see for instance the "Theories and Methodologies" section of issue 128 of the PMLA in 2013. 
premium on decorous conversation and refined display of persons and things" (Klein 2002: 886). The idea of politeness was to efface the performativity of the behaviour, and to establish a shared assumption of in-group belonging. Although the emphasis of public display meant "a new self-consciousness, new demands for kemptness" (ibid.: 887), the concept of politeness also "included such keywords as 'easiness', 'naturalness', and 'freedom' and sought to promote an ambience of reciprocity and equality" (ibid.: 879), The ideal was therefore a vision of an inclusive social context in which the members would feel at ease and 'know' that they naturally belonged there.

I will return to the question of the visibility of behaviour in circulating libraries below; here, I wish to make two basic points. First, apparently there was a large group of people who developed a common code of conduct by performing publicly and by maintaining a high level of mutual observation and implicit comparing. Second, I contend that the implicit practices of comparing were the guiding force behind the formation of ties and associations between humans, ideas, and artefacts. Comparing allows the inclusion of particular forms of behaviour and the exclusion of others.

The practice of reading and the materiality of the book were both involved in these implicit comparisons of public performance and in the creation of social associations. While reading is now mostly perceived to be a private, silent activity, it was frequently a communal one in the eighteenth century. Reading aloud among family and friends, or the household more generally, was still a widespread leisure pursuit, as Tadmor (1996) and Williams (2017) argue. Williams criticizes the tendency to correlate the spread of literacy with increasingly individual and silent reading. The fact that Mr Collins in Austen's Pride and Prejudice is not at all surprised by Mr Bennet's invitation to read to the women of the house can be seen as an indicator of the continuation of the practice into the nineteenth century. If book reading was a communal practice, book lending was a public one. The late seventeenth-century coffee house, which Habermas (1989) associated with the emergence of a genuine public sphere, had introduced the tradition of publicly accessible and rentable reading material (Kaufman 1967: 7-9). It may therefore have been customary for male readers to be seen going to an institution that provided print matter which could be read on the premises or taken out. In the eighteenth century, the publicness of book-lending was much increased by the general development of a consumer society that established modern practices of shopping as 
a social performance. ${ }^{17}$ It added middle-class women, in their role as shoppers, to the public scene. The display of affluence and taste became a form of self-expression and social positioning, as

cultural sites were places of self-presentation in which audiences made publicly visible their wealth, status, social and sexual charms. The ostensible reason for an individual's presence at a cultural site - seeing the play, attending an auction, visiting an artist's studio, listening to a concert [one might add: lending books; RS] - was often subordinate to a more powerful set of social imperatives. [...] And, from the individual's point of view, access to culture and self-presentation in the cultural arena was a means of maintaining or attaining social status and social distinctions. (Brewer 1995: 348$)^{18}$

The fact that new titles borrowed from a circulating library could be kept for as short a span as between two and six days (Erickson 1990: 580), while books that had been in stock for a while had a lease of up to a month (Jacobs 2006: 7), points to novels being much like articles of fashion, characterized by a high demand for continuous new output voiced by the consumers and satisfied by the producers.

To sum up the gist of the argument so far: Among the changes in eighteenth-century England were the simultaneous growth of consumerism, novel production and the circulating library, as well as the increasing socioeconomic power and visibility of the 'middling sorts'. The circulating libraries were predominantly frequented by persons from that social section, who turned book consumption to their public activities, aiming at performing behaviour that would be considered 'polite' in comparison with others who wished to situate themselves in that class. As I will go on to elucidate in more detail, the circulating libraries, the books they stored, the producers of fiction and its readers, were all agents in a network of sociability that was characterized by implicit shared expectations. Book consumption and the institution of the circulating library were, at the same time, confronted with quite ambivalent evaluations that resulted from the tension between politeness and consumerism.

17 On the development of the book as a commodity embedded in the wider growth of a consumer culture, see Raven (2009). 


\section{Assembling the Literary: Reciprocal Presuppositions and the Ambivalence of Novel Reading}

In his sophisticated reconsideration of the emergence of a public sphere (and its relation to the private) in eighteenth-century Britain, McKeon observes that we need to consider the public sphere as the product of both the material spaces and the ideas with which people brought that sphere into being: "The emergent public sphere was understood by contemporaries as a virtual collectivity, a metaphorical place of assembly constituted principally by publication and its readership. But it was also associated (unlike 'the public domain') with actual spaces" (McKeon 2006: 75). The circulating library was one of those spaces of assembly, both metaphorically and materially, and in that space, the shifting attitudes and evaluations met and were negotiated over the century. I will first look at evidence for the emergence of ties and associations between library owners, publishers, readers, books and the libraries themselves that are indicative of a virtual collectivity, and then explore the ambivalent evaluations connected with the lending of novels from circulating libraries that gave these spaces a distinct socio-cultural quality.

Four economic circumstances suggest that circulating library owners, publishers and readers, as well as books (as non-human agents), joined each other by and by in creating an atmosphere of mutual reliance. First, the practice of financing a new novel by subscription points to the production and reception of literature as providing a metaphorical place of assembly. Subscribers of circulating libraries in the late eighteenth century were frequently invited to pay for another subscription that would subsidize the publication of a new volume of fiction (Skelton-Foord 1999: 106-107). When such an invitation was successful, the lists of subscribers were frequently printed in the front matter of the finished book (Raven 2000: 55-56 and 111). Readers thus became also originators, patrons and proprietors of novels, and it would be a public fact that they did. Considering that anonymity was the rule for the first publication of a novel in the period (Raven 2003), it was the book as a material artefact and the ideas it stood for that appear as agents in the constellation, rather than authors. Even if the identity of an author was discovered and his or her name became associated with the book in question - a process in which circulating libraries had a hand, as Vareschi (2012) has shown - it would be more the idea of that author rather than the living individual, and as such, another non-human agent. Vareschi generalizes on the role of the circulating library and the book in ways that 
almost evoke an ANT framework, because he highlights the connections that emerged between groups of people and things:

As a medium for distributing texts, the circulating library is virtual and repetitive, more so than the bookshop. Selling a book entails acquiring private property, whereas renting a book involves many people in the common enterprise of sequential possession. Renting books carries with it the idea that books are interchangeable and exchangeable and thus function in the abstract both as commodities and as texts. Though the trade is of the material form of the book, the discrete book does not matter as much as its ability to be exchanged for another book, or [...] for other, variant editions. The distribution system contributes to the actual, physical book becoming a virtual entity shared among readers. (2012: 44; my emphases)

A book that people know has gone, and will continue to go, through several hands contributes to the creation of a sense of a shared social sphere; it establishes a link between the public availability of the object and the private realm of its consumption. Vareschi's notion of a "common enterprise of sequential possession" and the "virtual entity" that is "shared" can easily be understood in terms of links, ties, or associations between the people and artefacts involved in book-lending. Referring also to some other scholars who have emphasized the function of the circulating libraries to give their subscribers a feeling of belonging to an "imagined literary community", Vareschi sums up: "The circulating library, in effect, built a virtual literary public sharing a collection of texts and ideas that the library circulated" (ibid.: 45). The novel, with its focus on private lives that are turned public through the media genre itself, supported this circulation of ideas, which brought readers together also in a community of values.

Second, there were close ties between the production and the distribution of novels. Raven lists the four publishing houses that "boosted publication totals" and that later (in the last three decades of the century) dominated the market: "Thomas Hookham, the Robinsons, the Nobles (until 1789), and, from 1775, the newcomer and greatest novel manufacturer of all, William Lane" (2000: 73). Three of these enterprises (Hookham, the Nobles, and Lane) also ran circulating libraries. Thus, not all of the books they printed depended on the speculation whether a title would find a market; rather, these producers had parts of their own markets on the very premises. Although these markets did not absorb the entire production, since " 400 out of every 1.000 copies of novels were sold to circulating libraries", as markets they were nevertheless 
"limited, but at least knowable" (ibid.: 93). Since the circulating libraries by Hookham and Lane were the largest two in London (Skelton-Foord 1999: 92), their potency should not be underestimated. Many people in the metropolis therefore met in a fairly homogeneous cultural context, where book-lending and the reception of reading material were part of a mood of social closeness and belonging.

The apparent dependability of the business model of the circulating library thirdly manifests itself in another practice by which producers of books tried to ensure further distribution. John Lane, who founded the Minerva press in the late eighteenth century and produced highly successful popular sentimental and gothic fiction, sold "complete, packaged circulating libraries to new entrepreneurs" (Erickson 1990: 582, Raven 2000: 85). This implies that by then some standardization of taste must have taken place. Much like in the case of modern franchise enterprises, no businessman would have opened up such a venture if they had not trusted in the existence of a considerable demand and at least the promise of a reliable market. And the producer Lane must have relied on knowing what the readership wanted.

Fourth, retail business in the eighteenth century in general became increasingly competitive, which led to the rise of advertizing. Many advertisements for circulating libraries, and the catalogues they published, feature engravings that display the rooms in which the books were kept, the shelves to be browsed and the volumes to be checked out. ${ }^{19}$ As advertisements, they unsurprisingly tend to present rather idealized versions of the places, as some scholars have remarked (see Vareschi 2012: 28-30). One could compare this to the visual representation of modern restaurants or hotel websites on the internet: Once being confronted with the reality of a booked room or with a sophisticated dish, the premises hardly ever look exactly as splendid as the photo online did; the food on the plate in a restaurant never looks quite as tasty as the pictures that present the dishes on the venue's homepage. As advertisements, such images serve a twofold purpose. First and foremost, they present the actual space and what it has to offer in the best possible way, trying to evoke in the viewer a desire to go there. But another function is that they display both the atmosphere and the functional features of the place in a way that potential customers have an idea of the kind of place they might be visiting, and of how to behave - or, rather, perform - there. This was also

19 See the illustrations in Stewart-Murphy (1992), Raven (1996), Brewer (1997: 177-179), and Vareschi (2012). 
the case with the ads for the circulating libraries: The illustrations usually depicted not only the rooms and the bookshelves, but also customers in the libraries, and their clothes would provide hints as to the social affiliation of the establishment's clientele. The advertisement thus served as another agent in the network that connected literature, style, and middle-class behaviour.

It was mentioned above that book-lending was intricately connected with a broader set of public practices the middle-classes performed, among which shopping was central (Barry 1991; Berry 2002), ${ }^{20}$ partly because shops and libraries were public places, and partly because many circulating libraries were actually mixed businesses. A guide book on opening a circulating library from 1779 advises the entrepreneur to stock "Haberdashery, Hosiery, Hats, Tea, Tobacco and Snuffs; or Perfumery, and the sale of Patent medicines" in addition to books (qtd. in Skelton-Foord 1999: 109). Rural establishments also "often acted as ticket-selling agencies for operatic and theatrical productions in the capital" (ibid.: 107), and in seaside resorts, libraries also furnished articles that particularly the female customers desired, from trinkets and ornaments to luxury goods (see also Benson 1997). On the side of the entrepreneurs, such side lines of business may have been economically necessary in times when book-lending alone would not secure the proprietor a sufficient income. ${ }^{21}$ On the side of the consumers, going out to get reading material was closely connected with other shopping pleasures. Such public consumption elicited a range of ambivalent emotions between desire and shame that I take to bestow the particular social quality on the circulating library and its associations and that are therefore worth exploring further.

Among the attractions that brought people to the circulating libraries was the public visibility of the practice of book-lending itself. When people went out to rent a book, they could count on being seen, and to find a stage on which they could perform polite behaviour and compare and be compared with others. This is particularly true for the establishments in spa towns. The resorts were generally regarded as the meeting places of the well-to do, as marriage markets for middle-class families willing their daughters to marry

20 See also Klein (2002: 882): "Consumption was an important domain for the actuation of politeness because the spread of consumerism was characterized not just by quantitative increases but by qualitative alterations in the processes and meanings of acquisition."

21 Incidentally, our contemporary bookshops have reverted to that practice of offering a rather mixed range of goods. 
up the social scale, and as platforms for gossip of all kinds; the libraries provided a meeting opportunity for such purposes: "In the resorts the circulating libraries became fashionable daytime lounges where ladies could see others and be seen, where raffles were held and games were played, and where expensive merchandise could be purchased" (Erickson 1990: 576; my emphasis). ${ }^{22}$ Skelton-Foord remarks: "Time and again in accounts of late eighteenth- and early nineteenth-century library history it is written that popular fiction was being 'read to pieces'. But fictional representations of the circulating library suggest, albeit satirically, that within library buildings themselves almost anything other than reading was taking place" (1999: 105). Erickson emphasizes just how public it was to be a circulating-library user: "Since it was the custom to subscribe to the libraries immediately upon arrival in the watering places and resorts, their subscription books became a useful guide to who was in town" (1990: 567). Skelton-Foord also argues that the subscription book, which "was a customary record of business kept by the librarian [...] could also serve, like a register of fashionable society, to inform curious subscribers as to whom [sic] else was visiting the resort that season" (1999: 106). Even if not seen in person in the rooms of the library at all times, that is, people would still be publicly 'there' in their roles as subscribers, and as members of a community of fellow patrons, forming an imagined community. The social impact of this institution was helped by the sheer size of some establishments. One report from Margate, the fashionable watering resort, dating from the 1790 , praises a newly built circulating library featuring "a noble room" that was "large enough to contain between three and four hundred people" (qtd. in Kaufman 1967: 20). Late in the century, it appears, entrepreneurs could rely on an impressive demand from customers to have access to circulating library buildings.

Another desire, beside that to be seen, must have resided in the pleasures of shopping itself, which were closely associated with the sphere of literature, as was demonstrated above. These pleasures were, however, quite generally

On the watering places, see also Langford (2010: 395): "Between fashionable society with its ritual divisions of the of the year and its court-orientated timetables, and the despised fairs and holidays of the lower sort, there was a considerable gap, a gap which the new resorts filled with immense success and profit. They were essentially middleclass, [...] the bourgeois equivalent to the aristocrat's retreat to country-house life. Their underlying basis was the generally felt need for distinctively middle-class recreations. The use of fees and subscriptions ensured respectable company and a decently moneyed atmosphere." 
an ambivalent issue in the period, for consumption was fundamentally linked with guilt: The same period that championed a moral codex based on moderation, virtue and decency, which also fed into the concept of 'politeness', also saw the development of a culture of consumer good consumption and commodification, that was, in strictly moralist and religious terms, despicable or outright sinful. Nobody could deny that the cardinal sins of gluttony, greed, envy, and pride were dangerously close to the human motivations that make capitalism and consumer culture possible. The desire to possess things for their beauty rather than their necessity may have been considered frivolous, and the middle classes may have despised the aristocracy for their inclination towards luxury. But the many dressmakers, peruke-makers, milliners, hosiers, gold- and silversmiths, cabinet-makers, glass-blowers, potters, etc. who catered to the needs of the middle classes could not have thrived, had they not had customers both inclined and able to buy their wares. ${ }^{23}$

Another potential reason for a circulating-library user's guilty conscience was that guardians both of morality and literary quality looked down both upon the circulating library and the books they offered. According to Kaufman, the institution was regarded with some caution already when it first emerged: "As a new phenomenon it was automatically suspect" (1967: 23). The suspicion was perhaps due to the moral indignation about the other practices of public amusement practised there: "In fact, librarians organized a range of games and leisure pursuits in their establishments, including billiards, musical recitals, and balls, particularly in those libraries which were situated in large Assembly Rooms at fashionable resorts" (Skelton-Foord 1999: 108). This association of libraries with other amusements occurred not only in fact, it also affected the public perception of book lending. John and Francis Noble, who dominated the output of popular romance novels between the late 1730 s and the late 1780 s (see Raven 1990 and 2000: 74-75) were the victims of much moralising criticism, and were in the process lumped together with other activities that annoyed the moralizers: "Vilified as 'novel manufacturers' and hawkers of immoral and licentious literature, the Nobles were the literary equivalents of the managers of Ranelagh gardens or the masters of ceremonies at [...] spa resorts" (Raven 2000: 75). The reference to the Ranelagh pleasure gardens in Chelsea here is significant, because that place underwent

23 For a comprehensive discussion of the ambivalence between politeness and commerce in the development of modern English society in the eighteenth century, see Langford (1989); the issue is also discussed by Brewer (1995) and Klein (1995 and 2002). 
a process of 'gentrification' like many other forms of public entertainment throughout the century. While pleasure gardens in the early decades of the eighteenth century were associated with excessive drink, prostitution and violence, and regarded as "dangerous, disreputable, and therefore unfashionable" (Brewer 1997: 65), later in the century Ranelagh was considered to be "a sober and respectable venue" (ibid.). It was the most expensive of the establishments of this kind in and around London, its price of 2 shillings and sixpence more than doubling that of the rivalling Vauxhall pleasure garden in Kensington (ibid.: 66). The pleasure gardens were usually called "Ranelagh Gardens" or "Vauxhall Gardens" only - i.e., with the significant omission of the word "pleasure", perhaps to tone down the inutility of what would certainly be considered their attraction by their visitors. They would attract paying customers with the presentation of picture galleries, artistic performances, fireworks, dancing and other musical presentations. At Ranelagh, "[a]n orchestra and organist played music while fashionable men and women promenaded round the floor" of the main hall, and an eight-year old Wolfgang Amadeus Mozart performed his feats on the piano and organ there in 1764 (ibid.). It is difficult to assert to what extent the reputation of lowliness persisted and clung to the institution, even though, as the century proceeded, the customers of such sites were recruited increasingly from higher social strata.

Perhaps to counter such cultural depreciation, advertisements from circulating libraries did not tire of emphasizing their adherence to highest standards of quality and virtue (Manley 2000: 36-37 and 39-42). As the 1759 catalogue from a library in Kendal formulates it: "Several Books of Entertainment lately Published of which this Catalogue in part consists, are enrich'd with beautiful Examples, which by Vice's Folly are expos'd and appear in their natural deformity: from Books of this kind may be reaped great Advantages, by impressing right Principles with respect to Virtue, good sense and Manners" (qtd. in Manley 2000: 37). To argue that reading about the vices of others turns a person into a virtuous one would be to argue that nowadays people watch crime movies for the sake of learning how not to turn criminal. While it may have caused some subscribers considerable embarrassment that the circulating library was an institution associated with 'low' forms of public amusement, others were above such qualms, at least towards the end to the century. In a letter to her sister Cassandra of $18^{\text {th }}$ December 1798, Jane Austen famously wrote: 
I have received a very civil note from Mrs. Martin requesting my name as a Subscriber to her Library which opens the $14^{\text {th }}$ of January, \& my name, or rather Yours is accordingly given. My mother finds the Money. - Mary subscribes too, which I am glad of, but hardly expected. - As an inducement to subscribe, Mrs. Martin tells us that her Collection is not to consist only of Novels, but of every kind of literature, \&c. \&c. - She might have spared this pretension to our family, who are great Novel-readers and not ashamed of being so; - but it was necessary I suppose to the self-consequence of half her subscribers. (qtd. in Erickson 1990: 579; original emphasis)

The circulating library made the most recent fiction titles available, as well as classics, and it held many titles that were beyond all blame, generally offering a broad mixture that contained "good, bad, and indifferent" books, as many commentators had it in the late eighteenth century (Skelton-Foord 1999: 93). However, the negative judgment inherited from the early part of the period seems to have prevailed. Between the late seventeenth century and the middle of the eighteenth, the genre of prose fiction was predominantly associated with narratives of amorous intrigue, frequently translated from French or Italian, whose erotic appeal was deemed dangerous in particular to young female readers (Warner 1998) and the critical disdain for popular narratives also persisted in the second half of the century, as Taylor's early study (1943) shows. Female, young and uneducated readers were allegedly most susceptible to the lure of these novels, falling prey to confusing the unrealistic storyworlds of novels with their lived experience. It was against the backdrop of such widespread cultural vilification, as Warner (1998) argues, that writers like Henry Fielding and Samuel Richardson were able to create a morally elevated type of prose fiction. This suggests that towards mid-century, very different types of novels, linked to very different evaluations, coexisted on the British print market and on the shelves of the circulating libraries. The renting and reading of novels was thus a highly ambivalent social practice.

Public admittance of pursuing pleasures in a context that regards such pursuits as shameful requires strategies of justification: "Popular novel readers, insisting [...] on the improving qualities of their occupation, usually constructed defensive explanations for novel consumption" (Raven 2000: 113). I believe that the circulating library was a place in which admittance and justification, desire and shame management coexisted very closely. From a pragmatic point of view, book-lending did offer readers an opportunity to check out new novels instead of, or before, buying them. Clients could thus save 
money instead of wasting it on books that might turn out not to correspond to their tastes. A late eighteenth-century catalogue for John Bell's London circulating Library advertizes this by saying: "To enable every reader to form a proper judgment of Books before he becomes a purchaser of them" (qtd. in Skelton-Foord 1998: 350). This is just in keeping with ideals of parsimonious housekeeping and moderation that were widespread at the time. However, one could also always justify a visit to the circulating library by merely pretending to choose from a range of books that might be worth buying, even if one went there precisely for the thrill of taking out and reading the 'wrong' ones, i.e., the books one never planned to purchase and display on the bookshelves at home.

Mr Collins' choice of an alternative reading diet in the scene from Pride and Prejudice scene quoted at the beginning of this chapter is telling with regard to the alignment of the circulating library with desire and shame: James Fordyce was the very man who, in his two-volume work Sermons to Young Women of 1766, had ranted at novels for women as "an infernal brood of futility and lewdness" and stipulated that "she who can bear to peruse them must in her soul be a prostitute" (167-177; qtd. in Benson 1997: 205). Mr Collins' choice appears to him as an antidote to the potential infection through the lendinglibrary book from which he recoils. Kitty and Lydia, however, are aghast at being expected to feel ashamed for the borrowed book, which to them looks perfectly innocent, while to Collins it signifies illicit desire. The scene taking place roughly half a century after Fordyce's outburst, Austen's readers will have recognized how utterly out of date, unfashionable and unattractive unsexy, in modern terms - this makes Mr Collins as a potential suitor to one of the Bennett daughters, to say nothing of the chauvinistic patronising his outrageously exaggerated reaction implies. Austen must have relied on the efficiency of this indirect characterization of the young clergyman.

A final important issue implied in this scene is that this duality of desire and shame is inherent in the material artefact of the book itself, which would then affect the perception of the novel as a genre. The fact that "everything announced it to be from a circulating library", leading Mr Collins to shy away from it instinctively, refers to the fact that library novels with their "marble covers, spine-labels, and book plates, declared very clearly their origins" (Skelton-Foord 1998: 352, see also Erickson 1990: 573). The artefact can easily be slotted in the (imaginary) cultural hierarchy. The "marble bindings" are cheap pasteboard covers with a marble pattern, and only the spine was covered in leather, in contrast to the expensive leather binding that would 
cover the entire board of a book considered valuable enough to deserve such luxury. The alignment of knowing what type of book one held in one's hands and evaluating it touches upon more than the book cover: "the popular novel was judged in terms of the quality of its material existence - the clarity of its printing, the size and style of type and ornaments, their composition and arrangement on the page, and other design issues, including wrapping and binding" (Raven 2000: 103). As an agent in the nexus between public performance of polite sociability and the circulating library, the book itself appears as an ambivalent agent.

\section{Conclusion}

In eighteenth-century England, the development of the novel and the development of a middle-class mentality were closely associated. While literary and cultural historians have discussed this connection intensively, a look at the actual practices through which people got hold of books adds a fresh perspective to that connection. Members of the middle classes positioned themselves increasingly as 'polite shoppers' in the public sphere in that period, and I have argued that this public appearance was embedded in a framework of mutual comparison, in which practices of consumption were checked with regard to their meeting ideals of politeness. The rental of books and book distribution through the circulating library was one of the of areas that invited the comparison of behaviour deemed adequate for the broad and diverse social group that came to be called the middle class. The guiding principle of politeness was the ground for comparison, i.e., the tertium comparationis, while the two compared items, the primum comparandum and the secundum comparatum, were the observed behaviours of two agents; the primum comparandum could also be the observed behaviour of only one agent, while the ideal of polite behaviour constituted the secundum comparatum. Politeness was a central issue in the development of the social structure, because it helped to diffuse the boundaries between the upper classes and the middle: "While it was certainly easier for the gentleman of lineage and land to be polite, the individual who lacked those criteria for gentility might achieve or enhance a claim to gentility through his or her politeness himself" (Klein 2002: 876). Importantly, as an ideal, politeness was an abstract value that needed concrete practical realisations, and public arenas for the display of behaviours that could be classified as meeting the requirements. I have shown that the circulating libraries, with 
the ambivalent associations with elevated culture and entertainment, fashion, consumption and sociability it carried, emerged as exemplary arenas for the comparative performance of behaviour that straddled the divide between the middle and the upper classes. The involvement of the novel in this emerging arena, not only as a literary genre but, in its printed form as a material artefact, calls for an approach that goes beyond both established literary history and literary sociology.

From the perspective of literary scholarship, the social history of the book, Actor Network Theory and the study of practices of comparing may not be the most obvious candidates for an integrated approach, since they come from different disciplinary backgrounds, are based on different meta-theoretical positions and conceptual frameworks, and do not merge easily with the hermeneutic tradition of literary analysis and interpretation. As is obvious, in this article I have not even tackled the role that the contents and narrative strategies of eighteenth-century English novels played in the developments described. ${ }^{24}$ I have, however, tried to demonstrate that a literarysociological perspective that is aware of the relevance of practices, material artefacts, bodies, and ideas, directs our attention to the links between them, which account for the emergence of 'the social'. In the spirit of Actor Network Theory, I have therefore tried to shed light not on how book consumption happened 'in' eighteenth-century middle-class society, but on how a network of ties and associations between human and non-human agents - the clients of the circulating libraries, the libraries as social spaces, and the books themselves - as well as the practices linked with them emerged in the period under consideration, brought middle-class literariness into existence, and shaped it in particular ways that were different from both previous and later developments. ${ }^{25}$ As the observation of the changes in the period have shown, the circulating library and the novels it distributed made significant contributions to the emergence of a sphere in which the middle classes could increasingly

\footnotetext{
24 I do so elsewhere; see the contribution by Hartner/Schneider in this volume.

25 The nineteenth century saw a significant mainstreaming of the genre of the novel, of the institution of the circulating library, which became dominated by the two rivalling enterprises of Charles Edward Mudie and W. H. Smith, and of the material format of the novel, which was standardized into three volumes; at the same time, serial publication either in periodicals or individually sold installments, as well as one-volume cheaper reprints which became available at increasingly shorter distances from the first publication, multiplied the channels for the publication of fiction. For a concise survey of these developments, see Feather (1988: 129-179).
} 
rely on all actors being interested in establishing standards of politeness and maintaining the matching behaviour.

\section{Bibliography}

Adams, Thomas R. and Nicolas Barker. "A New Model for the Study of the Book." A Potencie for Life: Books in Society. Ed. Nicolas Barker. London: British Library, 1993. 5-43.

Austen, Jane. Pride and Prejudice. Ed. Donald Gray. New York: Norton, 2001 [1813].

Barry, Jonathan. "Consumers' Passions: The Middle Class in EighteenthCentury England.” Historical Journal 34 (1991): 207-216.

Barry, Johnathan and Christopher Brooks, eds. The Middling Sort of People: Culture, Society and Politics in England, 1550-1800. London: Palgrave Macmillan, 1994.

Belanger, Terry. "Publishers and Writers in Eighteenth-Century England." Books and their Readers in Eighteenth-Century England. Ed. Isabel Rivers. Leicester: Leicester University Press \& St. Martin's Press, 1982. 5-25.

Benedict, Barbara M. "Readers, Writers, Reviewers, and the Professionalization of Literature." The Cambridge Companion to English Literature, 1740-1830. Ed. Thomas Keymer and John Mee. Cambridge: Cambridge University Press, 2004. 3-23.

Benson, Mary Margaret. "Parasols \& Gloves \& Broches \& Circulating Libraries." Persuasions 19 (1997): 205-210.

Bermingham, Ann. "Introduction. The Consumption of Culture: Image, $\mathrm{Ob}-$ ject, Text." The Consumption of Culture, 1660-1800: Image, Object, Text. Ed. Ann Bermingham and John Brewer. London: Routledge, 1995. 1-20.

Bermingham, Ann and John Brewer, eds. The Consumption of Culture, 1660-1800: Image, Object, Text. London: Routledge, 1995.

Berry, Helen. "Polite Consumption: Shopping in Eighteenth-Century England." Transactions of the Royal Historical Society 12 (2002): 375-394.

Brewer, John. "The most polite age and the most vicious': Attitudes toward Culture as a Commodity, 1660-1800." The Consumption of Culture, 1660-1800: Image, Object, Text. Ed. Ann Bermingham and John Brewer. London: Routledge, 1995. 341-361.

Brewer, John. The Pleasures of the Imagination: English Culture in the Eighteenth Century. London: Harper Collins, 1997. 
Carter, Philip. Men and the Emergence of Polite Society: Britain 1660-1800. London: Routledge, 2001.

Cheah, Peng. "Grounds of Comparison." Grounds of Comparison: Around the Work of Benedict Anderson. Ed. Jonathan Culler and Peng Cheah. London: Routledge, 2003. 1-20.

Colclough, Stephen. Consuming Texts: Readers and Reading Communities, 16951870. Houndmills: Palgrave Macmillan, 2007.

Corfield, Penelope J. "Class by Name and Number in Eighteenth-Century Britain." Language, History, and Class. Ed. Penelope J. Corfield. Oxford: Oxford University Press, 1991. 101-130.

Corfield, Penelope J. "The Rivals: Landed and Other Gentlemen." Land and Society in Britain, 1700-1915: Essays in Honour of F.M.L. Thompson. Ed. B. Harte and R. Quinault. Manchester: Manchester University Press, 1996. 1-31.

Davidoff, Leonore and Catherine Hall. Family Fortunes: Men and Women of the English Middle Class, 1750-1850. Chicago: University of Chicago Press, 1987.

Downie, J. A. "How Useful to Eighteenth-Century English Studies is the Paradigm of the 'Bourgeois Public Sphere'?" Literature Compass 1 (2003): 1-19.

Earle, Peter. The Making of the English Middle Class: Business, Society and Family Life in London, 1660-1730. London: Methuen, 1989.

Erickson, Lee. "The Economy of Novel Reading: Jane Austen and the Circulating Library." Studies in English Literature, 1500-1900 30.4 (1990): 573-590.

Feather, John. A History of British Publishing. London: Routledge, 1988.

Feather, John. "The Book Trade and Libraries." The Cambridge History of Libraries in Britain and Ireland. Ed. Giles Mandelbrote and K. A. Manley. Vol. 2: 16401850. Cambridge: Cambridge University Press, 2006. 301-323.

Felski, Rita. The Limits of Critique. Chicago: Chicago University Press, 2015.

Felski, Rita and Susan Stanford Friedman. "Introduction." Comparison: Theories, Approaches, Uses. Ed. Rita Felski and Susan Stanford Friedman. Baltimore: Johns Hopkins University Press, 2013. 1-12.

Finkelstein, David and Alistair McCleery. The Book History Reader. 2nd ed. London: Routledge, 2006.

Garside, Peter, James Raven, and Rainer Schöwerling. The English Novel 17701829: A Bibliographical Survey of Prose Fiction Published in the British Isles. Vol. 1: 1770-1799. Oxford: Oxford University Press, 2000.

Genette, Gérard. Paratexts: The Thresholds of Interpretation. Trans. Jane E. Lewin. Cambridge: Cambridge University Press, 1997. 
Habermas, Jürgen. The Structural Transformation of the Public Sphere: An Inquiry into a Category of Bourgeois Society. Trans. Thomas Burger. Cambridge: MIT Press, 1989.

Hamlyn, Hilda M. "Eighteenth-Century Circulating Libraries in England." The Library, 5th Series, 1 (1946): 197-222.

Heintz, Bettina. "Wir leben im Zeitalter der Vergleichung: Perspektiven einer Soziologie des Vergleichens." Zeitschrift für Soziologie 45.5 (2016): 305-323.

Hume, Robert D. "The Economics of Culture in London, 1660-1740." Huntingdon Library Quarterly 69.4 (2006): 487-533.

Hunt, Margaret R. The Middling Sort: Commerce, Gender, and the Family in England, 1680-1780. Berkeley: University of California Press, 1996.

Hunter, J. Paul. Before Novels: The Cultural Contexts of Eighteenth-Century English Fiction. New York: W. W. Norton, 1990.

Hunter, J. Paul. "The Novel and Social/Cultural History." Cambridge Companion to the Eighteenth-Century Novel. Ed. John Richetti. Cambridge: Cambridge University Press, 1996. 9-40.

Jacobs, Edward. "Anonymous Signatures: Circulating Libraries, Conventionality, and the Production of Gothic Romances." ELH 62.3 (1995): 603-629.

Jacobs, Edward. "Eighteenth-Century British Circulating Libraries and Cultural Book History." Book History 6 (2003): 1-22.

Jacobs, Edward. "Circulating Libraries." The Oxford Encyclopedia of British Literature. Vol. 2. Ed. David Scott Kastan. Oxford: Oxford University Press, 2006. 5-10.

Kaufman, Paul. "The Community Library: A Chapter in English Social History." Transactions of the American Philosophical Society (new series) 57.7 (1967): 2-67.

Klein, Lawrence E. "Politeness for the Plebes: Consumption and Social Identity in early Eighteenth-Century England." The Consumption of Culture, 16601800: Image, Object, Text. Ed Ann Bermingham and John Brewer. London: Routledge, 1995. 362-382.

Klein, Lawrence E. "Politeness and the Interpretation of the British Eighteenth Century." The Historical Journal 45.4 (2002): 869-898.

Langford, Paul. A Polite and Commercial People: England 1727-1783. Oxford: Clarendon Press, 1989.

Langford, Paul. "The Eighteenth Century, 1688-1789." The Oxford History of Britain. Ed. Kenneth O. Morgan. Updated edition. Oxford: Oxford University Press, 2010. 390-469. 
Latour, Bruno. "On Actor-Network Theory: A Few Clarifications." Soziale Welt 47.4 (1996): 369-381.

Latour, Bruno. "On Recalling ANT." Actor Network Theory and After. Ed. John Law and John Hassard. Oxford: Blackwell and the Sociological Review, 1999. 1525.

Latour, Bruno. Reassembling the Social: An Introduction to Actor-Network Theory. Oxford: Oxford University Press, 2005.

Luhmann, Niklas. "The Differentiation of Society." Trans. Stephen Holmes and Charles Lamore. Canadian Journal of Sociology 2.1 (1977): 29-53.

Manley, K. A. "Booksellers, Peruke-Makers, and Rabbit-Merchants: The Growth of Circulating Libraries in the Eighteenth Century." Libraries and the Book Trade. Ed. Robyn Myers, Michael Harris, and Giles Mandelbrote. Newcastle: Oak Knoll Press, 2000. 29-50.

McKendrick, Neil, John Brewer, and J.H. Plumb. The Birth of a Consumer Society: The Commercialisation of Eighteenth-Century England. Bloomington: Indiana University Press, 1982.

McKenzie, D. F. Bibliography and the Sociology of Texts. London: The British Library, 1986.

McKeon, Michael. The Origins of the English Novel, 1600-1740. Baltimore: Johns Hopkins University Press, 2002 [1987].

McKeon, Michael. The Secret History of Domesticity: Public, Private, and the Division of Knowledge. Baltimore: Johns Hopkins University Press, 2006.

McKillop, Alan. "English Circulating Libraries, 1725-1750." The Library, 4th Series, 14 (1934): 477-485.

Morse, David. The Age of Virtue: British Culture from the Restoration to Romanticism. Houndmills: Palgrave Macmillan, 2000.

Nunn, Joan. Fashion in Costume, 1200-2000. 2nd ed. Chicago: New Amsterdam Books, 2000.

Parsons, Talcott. Politics and Social Structure. New York: Free Press, 1969.

Pennell, Sara. "Consumption and Consumerism in Early Modern England." Historical Journal 42.4 (1999): 549-564.

Porter, Roy. English Society in the Eighteenth Century. 2nd ed. Harmondsworth: Penguin. 1991.

Raven, James. "The Noble Brothers and Popular Publishing." The Library, 6th Series, 12 (1990): 293-345.

Raven, James. "From Promotion to Proscription: Arrangements for Reading and Eighteenth-Century Libraries." The Practice and Representation of Read- 
ing in England. Ed. James Raven, Helen Small, and Naomi Tadmor. Cambridge: Cambridge University Press, 1996. 175-201.

Raven, James. "Historical Introduction: The Novel Comes of Age." The English Novel 1770-1829: A Bibliographical Survey of Prose Fiction Published in the British Isles. Vol. 1: 1770-1799. Ed. James Raven and Antonia Fraser. Oxford: Oxford University Press, 2000. 15-121.

Raven, James. "Libraries for Sociability: The Advance of the Subscription Library." The Cambridge History of Libraries in Britain and Ireland. Vol. 2: 16401850. Ed. Giles Mandelbrote and K. A. Manley. Cambridge: Cambridge University Press, 2006. 241-263.

Raven, James. "The Book as a Commodity." The Cambridge History of the Book in Britain. Ed. Michael F. Suarez and Michael L. Turner. Vol. 5. Cambridge: Cambridge University Press, 2009. 85-117.

Raven, James. What is the History of the Book? Cambridge: Polity Press. 2018.

Ribeiro, Aileen. Dress in Eighteenth-Century Europe, 1715-1798. Rev. ed. New Haven: Yale University Press, 2002.

Rivers, Isabel, ed. Books and their Readers in Eighteenth-Century England. Leicester: Leicester University Press \& St. Martin's Press, 1982.

Skelton-Foord, Christopher. "To Buy or to Borrow? Circulating Libraries and Novel Reading in Britain, 1778-1828." Library Review 47.7 (1998): 348-354.

Skelton-Foord, Christopher. "Surveying the Circulating Library Scene: Popular British Fiction, 1770-1830." Bibliotheken in der literarischen Darstellung: Libraries in Literature. Ed. Peter Vodosek and Graham Jefcoate. Wiesbaden: Harrassowitz, 1999. 89-113.

Slack, Paul. The Invention of Improvement: Information and Material Progress in Seventeenth-Century England. Oxford: Oxford University Press, 2015.

Smail, John. The Origins of Middle-Class Culture: Halifax, Yorkshire, 1660-1780. Ithaca: Cornell University Press, 1994.

Spurr, John. "England 1649-1740: Differences Contained?" The Cambridge Companion to English Literature 1650-1740. Ed. Steven N. Zwicker. Cambridge: Cambridge University Press, 1998. 3-32.

Stein, Jordan Alexander. When Novels Were Books. Cambridge: Harvard University Press, 2020.

Stewart-Murphy, Charlotte. A History of British Circulating Libraries: The Book Labels and Ephemera of the Papantonio Collection. Newton: Bird and Bull Press, 1992.

Styles, John. The Dress of the People: Everyday Fashion in Eighteenth-Century England. New Haven: Yale University Press, 2007. 
Tadmor, Naomi. "In the even my wife read to me': Women, Reading and Household Life in the Eighteenth Century." The Practice and Representation of Reading in England. Ed. James Raven, Helen Small, and Naomi Tadmor. Cambridge: Cambridge University Press, 1996. 162-174.

Taylor, John Tinnon. Early Opposition to the English Novel: The Popular Reaction from 1760-1830. New York: King's Crown, 1943.

Vareschi, Mark. "Attribution and Repetition: The Case of Defoe and the Circulating Library." Eighteenth-Century Life 36.2 (2012): 36-59.

Wahrman, Dror. Imagining the Middle Class: The Political Representation of Class in Britain, c.1780-1840. Cambridge: Cambridge University Press, 1995.

Warner, William. Licensing Entertainment: The Elevation of Novel Reading in Britain, 1684-1750. Berkeley: University of California Press, 1998.

Watt, Ian. The Rise of the Novel: Studies in Defoe, Richardson and Fielding. London. Chatto \& Windus, 1957.

Williams, Abigail. The Social Life of Books: Reading Together in the EighteenthCentury Home. New Haven: Yale University Press, 2017. 